\title{
ENVIRONMENTAL CONSTRAINTS ON THE INTERDEPENDENCE OF DRAINAGE BASIN MORPHOMETRIC PROPERTIES IN THE UPPER CROSS RIVER.
}

\section{CHARLES UDOSEN}

(Received 27 August, 2008; Revision Accepted 22 April, 2009)

\begin{abstract}
This study seeks to identify the effects of environmental heterogeneity on the interdependence of drainage basin morphometric properties and its implications for applied studies-particularly flood abatement/control. A detailed morphometric analysis of $223^{\text {rd }}$ - order streams in the upper Cross River basin was carried out. At least six $3^{\text {rd }}$ order streams were chosen from diverse geologic formations- Precambrian Basement Complex rocks and Asu River Formation in Abakaliki and Ikom-Mamfe Formation. The thirteen measured/derived data on the morphometric parameters were tested for normality and logarithm transformation was carried out. The SPSS soft ware was employed to generate a correlation matrix using the transformed data set. The transformed data matrix was also subjected to principal component analysis. The principal components having eigen-values greater than 1.0 were rotated using the varimax method in order to produce an orthogonal transformation of the components and simplify interpretation. The results indicate that the degree of inter-correlations among the thirteen morphometric variables is weak. Only $32.1 \%$ of the 78 possible relationships were significant at 0.05 level. We do know that an increase in the interdependence of the morphometric properties of drainage basins is indicative of a lessening of environmental constraints [lithology] on the stochastic processes that generate stream networks. The result of Principal Component Analysis shows that the four factor model account for $83.90 \%$ of the variation in the original data. For example factor1 [index of drainage dissection] explains $36.55 \%$ of the variation in the data and is inversely related to basin size. The infrequent occurrence of flooding in the basin is caused by rain-swollen tributaries discharged into main channel at different periods.
\end{abstract}

KEYWORDS: Factor analysis, Lithology, Nigeria, Basement complex, Eigen Value, Morphometry

\section{INTRODUCTION}

The literature is replete with studies on the relationships between the morphometric properties of drainage basin Gregory and Walling, 1973, Doornkamp and King, 1971, Ebisemiju,1976,1985,1987; Morisawa,1968; Ukpong, 2005 and Udosen, 2008). These investigations, done in a wide range of geologic and climatic environments, have revealed that although there are regional variations in the morphology of fluvially- dissected landscapes, most of the geomorphometric parameters which have been derived for the quantitative analysis and description of the planimetric and relief aspects of their drainage basins are interrelated. The intercorrelation structures obtained, however, differ not only in the number, identity, and relative importance of the underlying dimensions and their defining variables but also in the signs of the correlations (Ebisemiju, 1986)

Furthermore, Gardiner (1978,) noted that 'the differences between results may be attributable to either the mix of variables used or to the geomorphologic conditions specific to individual studies or indeed, to both. Empirical studies in the Scotland District in the Caribbean Island of Barbados revealed that the erosional degradation of relief and topographical position are important constraints on the organization and interaction amongst the morphometric attributes of drainage basins (Ebisemiju, 1986).

This serves as springboard for further investigations in this aspect by other researchers. Thus, the present research is an attempt to establish relationships between the morphometric properties of Cross River system in relation to the geology.

The study specifically seeks to identify the effects of environmental heterogeneity on the interdependence of drainage basin morphometric properties and its implications for applied studiesparticularly flood abatement/control.

\section{MATERIALS AND METHODS}

\section{Study area}

This study was conducted in the upper Cross River Basin. The study area stretches from latitude $6^{\circ} 34$ $30 \mathrm{~N}$ and longitude $8^{\circ} 4619 \mathrm{E}$ in Abakaliki (Ebonyi state) to latitude $6^{\circ} 3851 \mathrm{~N}$ and longitude $9^{\circ} 0924 \mathrm{E}$ in Obudu, Cross River state (fig.1). 


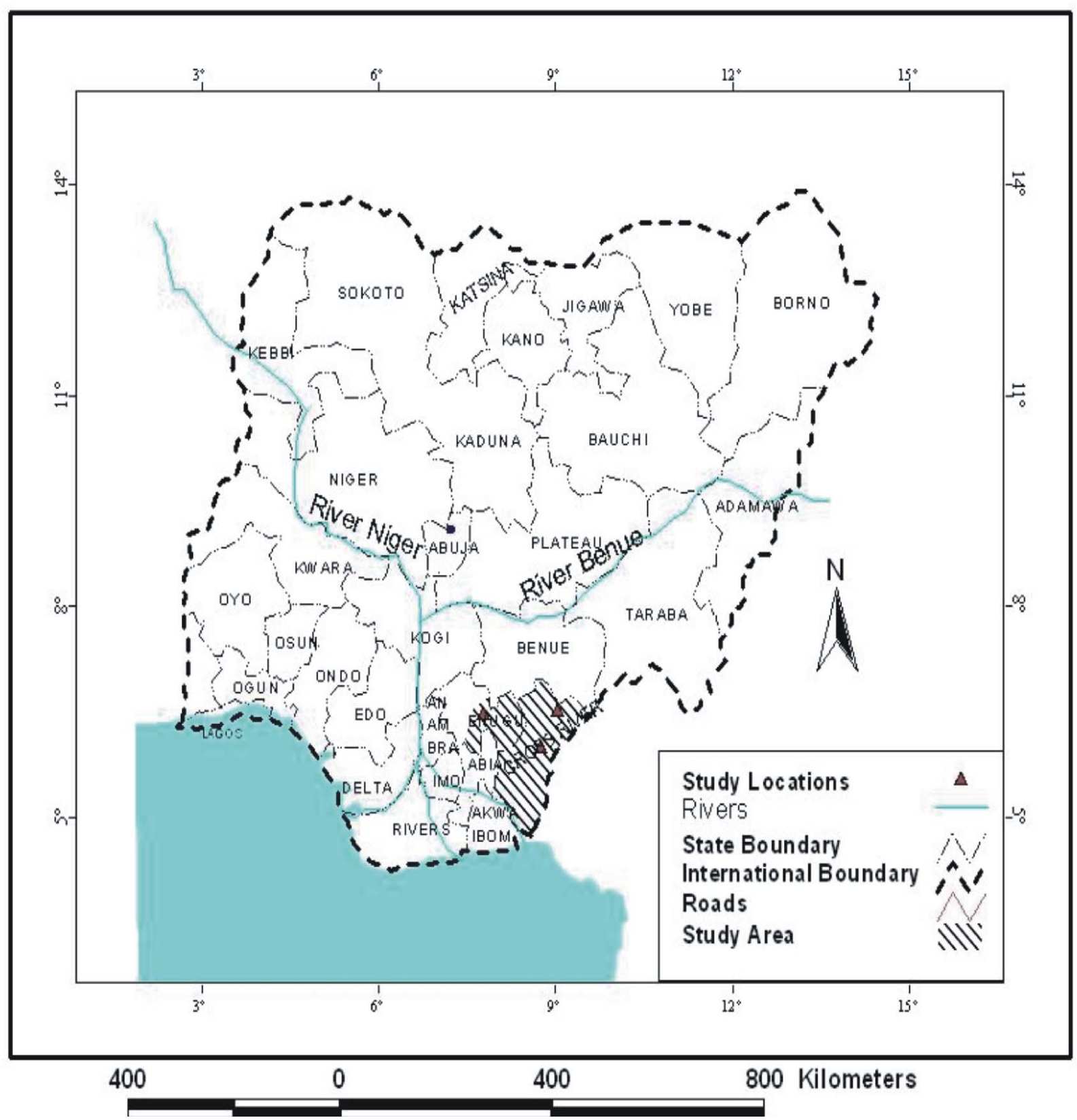

Figure 1: Location of the Study Area in Nigeria

The study area is underlain by a wide range of diverse geological formations ranging from the ancient metamorphic rocks- the Precambrian Basement Complex from Ogoja to Obudu to the sedimentary rocks of Asu River Formation, e.g the Mamfe rift in Ikom and the Abakaliki Anticlinorium of the Asu River Formation in Ebonyi state axis of the study area. (fig.2). 


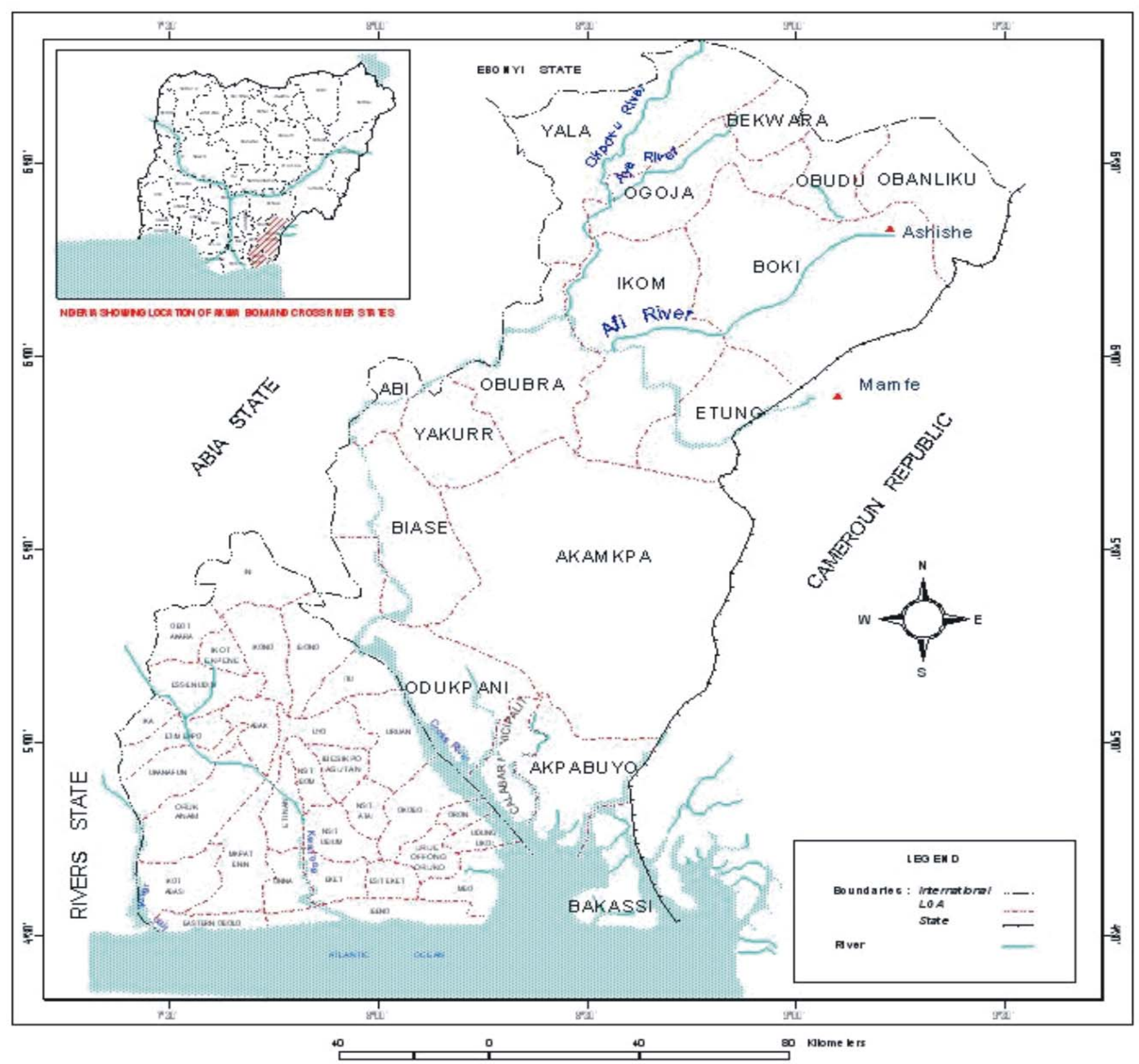

Figure 2: The Cross River Basin showing the locations of the investigated streams

The climate of the area varies from the humid tropical climate, designated Af climate type (Thornthwaite,1948] in Abakaliki, Ikom and other locations south of Boki local government area to the Montane climate type found on the mountain range of Obudu Plateau. In the Obudu Cattle Ranch the effects of high altitude $(600-2000 \mathrm{~m}$ a.s.I.) has modified the temperature, humidity and rainfall pattern and the area is characterized by frequent occurrence of light rainfall (mainly orographic rainfall); very cold and chilly nights, sometimes close to $5-10^{\circ} \mathrm{C}$.

Ogoja for instance recorded a mean annual of 1700.3mm (recorded between 1993 and 2005). Ikom station recorded a total annual rainfall of $2225.7 \mathrm{~mm}$ in 2002 and $2411.6 \mathrm{~mm}$ in 2007 (Nimet, Calabar Airport).

On the other hand, Obudu received an average annual rainfall of $1918.95 \mathrm{~mm}$ between 1995 and 2003 (Nimet, Calabar Airport, 2004]. The least was recorded in 2001(1570.3mm), while the highest was in 1997 (2540.8mm). The frequency of occurrence of rainfall in the Obudu area is 113 rain-days in every year. (Nimet,
Calabar, 2006). The duration of the wet and dry seasons is seven and five months respectively.

At lkom, the maximum temperature ranges from $28.4-35.3^{\circ} \mathrm{C}$. The minimum values could be as low as $24^{\circ} \mathrm{C}, \quad$ as observed during field investigations/measurements. The relative humidity values are high at Ikom (75-90\%), while the wind speed ranges from 11.42 - 29.33knots respectively. Temperature values recorded in wet season (May) fluctuates between $23.5^{\circ} \mathrm{C}$ and $33^{\circ} \mathrm{C}$, with a mean value of $29.91^{\circ} \mathrm{C}$. Relative humidity, wind speed and atmospheric pressure were $39-85 \%, 0.5-1.5 \mathrm{~m} / \mathrm{s}$ and $747.1-747.8 \mathrm{mmHg}$ respectively. Their mean values are $67.5 \%, 0.77 \mathrm{~m} / \mathrm{s}$ and $747.3 \mathrm{mmHg}$ (Nimet, Calabar, 2007)

\section{Analysis of Morphometric Properties}

At least six third order streams were chosen from the Precambrian Basement Complex rocks; another six from the Abakaliki Anticlinorium-Asu River Formation and the Mamfe Formation. The entire stream 
network in the study area was traced onto a tracing paper stream ordering was carried out, while the outline of the stream network was transferred onto a graph paper and used in computing the basin area-using the squares method.

Morphometric data were measured/derived from the analysis of $1 ; 50,000$ topographical maps with $15 \mathrm{~m}$ contour interval (converted from 50ft intervals)

The stream network was ordered using Strahler's method of stream ordering (Strahler, 1952). The stream network shown in blue on the base maps in Sheet numbers 315NW, 304SE and 304SW was supplemented by channels whose existence was inferred from v-shaped contour crenulations (Morisawa, 1957) $1 ; 50,000$ It involved a detailed morphometric analysis of all the stream segments in Sheet numbers 315NW, 304SE and 304SW. Topographical maps were traced onto tracing paper. This was then used in stream ordering and calculation of bifurcation ratio. The basin length was measured as the straight line distance between the mouth of the basin and the farthest distance to the drainage divide $\left[L_{B}\right]$; the difference between the highest point and the elevation of the basin at the gauging station-basin outlet $\left[\mathrm{H}_{B}\right]$ is the basin relief; basin slope[S] is $H_{B} / L_{B}$; stream frequency is number of streams/unit area while the drainage density is total length of streams in kms per unit area expressed as $\mathrm{km} / \mathrm{km}^{2}$. The reciprocal of drainage density is known as the mean length of overland flow. The bifurcation ratio was measured as the total number of stream segments of a particular order divided by the next higher order. (Gregory and Wallings, 1973).

Basin shape has proved to be one of the most elusive topographic properties to measure unambiguously with accuracy, significance and precision. In this study, the methods employed are summarized below;

Table 1 Measurement of Drainage Basin Shape

\begin{tabular}{|l|l|l|}
\hline Index of basin shape & Methodology & Source \\
\hline Form factor & $\begin{array}{l}\mathrm{F}=\mathrm{A} / \mathrm{L}^{2} \\
\text { wher } \mathrm{A} \text { is basin area and } \mathrm{L} \text { is basin length }\end{array}$ & Hortorn,[1932] \\
\hline Basin circularity & $\begin{array}{l}\text { Rc=Area of basin/Area of circle with same } \\
\text { perimeter }\end{array}$ & Miller, 1953] \\
\hline Basin elongation & $\begin{array}{l}\text { Diameter of circle with same area as } \\
\text { basin/Basin length }\end{array}$ & Schumm,[1956] \\
\hline Lemniscate K & $\mathrm{L}^{2} / 4 \mathrm{~A}$ & $\begin{array}{l}\text { Chorley, Malm and Pogorzelski, } \\
{[1957]}\end{array}$ \\
\hline
\end{tabular}

Source ; Gregory and Walling, [1973;51]

The width, length and depth of stream channels were measured with a $30 \mathrm{~m}$ linen tape. The velocity of channel flow was measured at different points using the floatation technique; water depths were measured using a weighted graduated chord (Brassington 1988). Information on water uses was gathered through direct interview and personal observations.

The flow velocity at a mean depth $(0.6$ of total depth) i.e. mean flow velocity was determined from the relation given by Linsley et al1982 and quoted in Ayoade (2004). $\mathrm{V}=\mathrm{v}^{1}[\mathrm{z} / \mathrm{h}]^{1 / 7}$

Where $\mathrm{V}$ is the mean velocity, $\mathrm{v}^{1}$ velocity determined from float, $\mathrm{h}$ is the depth corresponding to the 0.6 of maximum depth and $Z=n^{1} / 30$ where $n^{1}$ is the streambed roughness coefficient.

\section{Data analysis}

The measured/derived data were tested for normality and logarithm transformation was carried out. Prior to this, the mean, standard deviation, range and coefficient of variation were computed for each of the parameters. The SPSS soft ware was employed to generate a correlation matrix using the transformed data set. The transformed data matrix was also subjected to principal component analysis. The principal components having eigen-values greater than 1.0 were rotated using the varimax method in order to produce an orthogonal transformation of the components and simplify interpretation.

\section{RESULTS AND DISCUSSION}

The Cross River covers nearly $52,000 \mathrm{~km}^{2 !}$. (CRBDA,2006) The headwater is Mun-Aya river which is located south of Mamfe in Cameroon mountain. In Nigeria it flows westwards, through Ajasso, Ikom, Ofumatan and Obubra before it changes direction southwards, through Itu, where it receives the waters of Enyong Creek, and Nwaniba where it also receives Ikpa river basin at Edik Ikpa and finally to Oron. The Calabar River joins the system near Oron and together it empties into the Atlantic Ocean, As expected, the main source of water in the study area is precipitation, hence the basin has a very high runoff coefficient (Table 2). 
Table 2: Runoff Coefficient in the Study Area

\begin{tabular}{|c|c|c|c|c|c|c|}
\hline $\begin{array}{l}\text { Drainage } \\
\text { Basin }\end{array}$ & $\begin{array}{l}\text { Total } \\
\text { area }\left[\mathrm{km}^{2}\right]\end{array}$ & $\begin{array}{l}\text { Precipitation } \\
{[\mathrm{mm}]}\end{array}$ & $\begin{array}{l}\text { Evapotran } \\
\text { spiration } \\
{[\mathrm{mm}]}\end{array}$ & $\begin{array}{l}\text { Runoff } \\
\text { [mm] }\end{array}$ & $\begin{array}{l}\text { Runoff } \\
\text { Coefficient }\end{array}$ & Settlements \\
\hline Upper Cross River & 15,932 & 3178 & 1231 & 1947 & 0.61 & $\begin{array}{l}\text { lkom, Nde } \\
\text { Etc. }\end{array}$ \\
\hline Central Cross River & 942 & 2112 & 1192 & 950 & 0.45 & $\begin{array}{l}\text { Ofunatam, } \\
\text { Ngo, Ofofadim, } \\
\text { Obubra }\end{array}$ \\
\hline Afi River & 1532 & 2217 & 1177 & 1034 & 0.47 & $\begin{array}{l}\text { Afi, Mgbaka, } \\
\text { Edor, Nkum etc }\end{array}$ \\
\hline Abonyi River & 1834 & 2017 & 1145 & 872 & 0.43 & $\begin{array}{l}\text { Abakaliki, Juju } \\
\text { hill, Nchako, } \\
\text { Amachi, } \\
\text { Izekwe - Noyo } \\
\text { and Oturekpe }\end{array}$ \\
\hline Aya River & 2664 & 1941 & 1122 & 819 & 0.42 & Obudu \\
\hline Amire River & 540 & 2202 & 1104 & 918 & 0.42 & $\begin{array}{l}\text { Obanlike and } \\
\text { Obudu Ranch }\end{array}$ \\
\hline
\end{tabular}

Source; Data analysis from CRBDA[Hydrology Map]

The summary of morphometric properties of 22 third order basins in the upper Cross River system is provided in table 3.

Table 3: Drainage Basin Morphometry - Order 3

\begin{tabular}{|l|l|l|l|l|}
\hline PARAMETERS & RANGE & MEAN & STD DEVIATION & C.V. \\
\hline Basin Area $\left[\mathrm{Km}^{2}\right]$ & $6.69-126.75$ & 37.62 & 30.70 & $81 \%$ \\
\hline Basin relief $[\mathrm{m}]$ & $3.81-716.28$ & 122.06 & 216.43 & 175 \\
\hline Mean length of streams[km] & $0.38-3.09$ & 1.08 & 0.53 & $49 \%$ \\
\hline Channel slope[degrees] & $0.04-9.00$ & 3.37 & 2.62 & $77.7 \%$ \\
\hline Bifurcation ratio & $2.50-7.10$ & 3.53 & 1.15 & 32.6 \\
\hline Stream frequency & $0.00-1.27$ & 0.56 & 0.37 & $66.1 \%$ \\
\hline Drainage density[[Km/Km ${ }^{2]}$ & $0.28-1.75$ & 0.90 & 0.42 & $46.7 \%$ \\
\hline Drainage intensity & $0.00-2.112$ & 0.61 & 0.61 & 100 \\
\hline Mean length overland-flow[km] & $0.57-3.57$ & 1.45 & 0.87 & $60 \%$ \\
\hline Form factor & $0.01-0.34$ & 0.12 & 7.49 & - \\
\hline Circularity ratio & $0.09-1.89$ & 0.66 & 0.5 & $75.8 \%$ \\
\hline Elongation ratio & $0.01-0.10$ & 3.5 & 2.37 & $67.7 \%$ \\
\hline Lemniscate -K & $0.74-6.54$ & 2.2 & 1.39 & $63.2 \%$ \\
\hline
\end{tabular}

Much controversy exists among fluvial geomorphologists on the role of relief in controlling the dissection texture in fluvially eroded landscapes (Udosen, 2008). In the study area, local relief[ relative relief] and stream gradients were employed to characterize the relief features. The local relief ranged from $3.81 \mathrm{~m}$ to $716 \mathrm{~m}$ above sea level, with a mean value of $38 \mathrm{~m}$ a.s.I. and C.V. of $175 \%$.. It is clear from Table 2 that the values of local relief and stream gradient are highly variable. The values of the bifurcation ratio is the least variable in the basin, with a C.V. of $32.6 \%$ and ranges from 2.5 to 7.1 , mean $=3.53$ $\mathrm{sd}=1.15$. Often, the stream segments are U-shaped, narrow and swift flowing, where the thick deposits of clay impedes valley bottom erosion
On account of very high relief, particularly around Obudu Plateau, the mean length of unbranched streams-order 1 are short $(0.38-3.09 \mathrm{~km}$, mean $=1.08, \mathrm{sd}=0.53$ and C.V. $=49 \%$ ). In the highly fissured quartzite and quartzschist[Basement Complex rocks of western Nigeria] of Effon Alaaye in Western Nigeria, Jeje[1991] recorded a mean length of $0.37 \mathrm{~km}$, with stream gradients ranging from $3^{\circ}$ to $17.5^{\circ}$ and reported that' the river system contains immense potential energy which can only be dissipated through the processes of erosion, lateral expansion and channel incision.' 
Table 4: Inter-dependence of drainage basin morphometric parameters

\begin{tabular}{|c|c|c|c|c|c|c|c|c|c|c|c|c|c|}
\hline- & $\mathrm{X} 1$ & $\mathrm{X} 2$ & $\mathrm{X3}$ & $\mathrm{X} 4$ & $\mathrm{X} 5$ & $\mathrm{X} 6$ & $\times 7$ & $\mathrm{X} 8$ & $\times 9$ & $\mathrm{X} 10$ & $\mathrm{X} 11$ & $\mathrm{X} 12$ & $\mathrm{X} 13$ \\
\hline $\begin{array}{l}\text { Area } \\
\mathrm{X} 1\end{array}$ & - & & & & & & & & & & & & \\
\hline $\begin{array}{l}\text { b.relief } \\
\text { X2 }\end{array}$ & -0.22 & - & & & & & & & & & & & \\
\hline $\begin{array}{l}\text { Str. } \\
\text { Length } \\
\text { X3 }\end{array}$ & 0.31 & $\overline{0}-\overline{07}$ & - & & & & & & & & & & \\
\hline $\begin{array}{l}\text { Chan. } \\
\text { slope } \\
\text { X4 }\end{array}$ & 0.35 & 0.15 & $\begin{array}{l}0.47 \\
*\end{array}$ & - & & & & & & & & & \\
\hline $\begin{array}{l}\text { Bifur. ratio } \\
\times 5\end{array}$ & $\begin{array}{l}0.65 \\
* *\end{array}$ & $\overline{0}-24$ & $\begin{array}{l}- \\
0.14\end{array}$ & 0.22 & - & & & & & & & & \\
\hline $\begin{array}{l}\text { Str. Freq. } \\
\text { X6 }\end{array}$ & $\begin{array}{l}- \\
0.68\end{array}$ & 0.20 & $\overline{0}-23$ & $\overline{0}-17$ & $\overline{0}-06$ & - & & & & & & & \\
\hline $\begin{array}{l}\text { Ddensity } \\
\text { X7 }\end{array}$ & $\begin{array}{l}- \\
0.77 \\
* *\end{array}$ & 0.15 & $\overline{0}-12$ & $\begin{array}{l}- \\
0.18\end{array}$ & $\overline{-}-25$ & $\begin{array}{l}0.67^{*} \\
*\end{array}$ & - & & & & & & \\
\hline $\begin{array}{l}\text { D. inten. } \\
\text { X8 }\end{array}$ & $\begin{array}{l}- \\
0.81\end{array}$ & 0.19 & $\overline{-}-39$ & $\overline{0} .28$ & $\overline{0}-13$ & $\begin{array}{l}0.76^{*} \\
*\end{array}$ & $\begin{array}{l}0.9 \\
5^{* *}\end{array}$ & - & & & & & \\
\hline $\begin{array}{l}\text { Overland } \\
\text { flow } \\
\text { X9 }\end{array}$ & $\begin{array}{l}0.77 \\
\star *\end{array}$ & $\begin{array}{l}- \\
0.15\end{array}$ & 0.14 & 0.18 & 0.25 & $\begin{array}{l} \\
0.68^{*} \\
*\end{array}$ & $\begin{array}{l}-\overline{1.0} \\
0^{* *}\end{array}$ & $\begin{array}{l}- \\
0.94 \\
* *\end{array}$ & - & & & & \\
\hline $\begin{array}{l}\text { Form } \\
\text { factor } \\
\mathrm{X} 10 \\
\end{array}$ & 0.07 & 0.40 & 0.35 & $\overline{-}-08$ & 0.03 & 0.08 & $\begin{array}{l}0.1 \\
2\end{array}$ & 0.16 & $\overline{-}-12$ & - & & & \\
\hline $\begin{array}{l}\text { Circ. } \\
\text { Ratio } \\
\text { X11 }\end{array}$ & $\begin{array}{l}- \\
0.84 \\
*\end{array}$ & 0.15 & $\overline{-}-36$ & $\overline{-}-19$ & $\begin{array}{l}- \\
0.43 \\
*\end{array}$ & $\begin{array}{l}0.66^{*} \\
*\end{array}$ & $\begin{array}{l}0.5 \\
8^{* *}\end{array}$ & $\begin{array}{l}0.69 \\
* *\end{array}$ & $\begin{array}{l}- \\
0.58 \\
* *\end{array}$ & -0.07 & - & & \\
\hline $\begin{array}{l}\text { Elongatio } \\
\mathrm{n} \\
\mathrm{X} 12\end{array}$ & $\begin{array}{l}- \\
0.44 \\
*\end{array}$ & $\begin{array}{l}0.42 \\
*\end{array}$ & 0.16 & $\overline{-}-32$ & $\begin{array}{l}0.54 \\
*\end{array}$ & 0.33 & $\begin{array}{l}0.2 \\
4\end{array}$ & 0.22 & $\overline{-}-25$ & $0.50^{*}$ & 0.24 & - & \\
\hline $\begin{array}{l}\text { K-factor } \\
\text { X13 }\end{array}$ & -0.18 & $\begin{array}{l}- \\
0.27\end{array}$ & $\begin{array}{l}- \\
0.45 \\
*\end{array}$ & $\overline{-} .12$ & 0.17 & 0.09 & $\begin{array}{l}0.2 \\
3\end{array}$ & 0.29 & $\overline{-} .24$ & $\begin{array}{l}- \\
0.68^{*} \\
*\end{array}$ & 0.26 & $\begin{array}{l}- \\
0.77 \\
* *\end{array}$ & - \\
\hline
\end{tabular}

* significant at 0.05 level

** significant at 0.01 level

The correlation coefficient matrix presented in Table 4 reveals that the degree of inter-correlations among the thirteen morphometric variables is weak. Only $32.1 \%$ of the 78 possible relationships are significant at 0.05 level. Abrahams (1972) has suggested that an increase in the interdependence of the morphometric properties of drainage basins is indicative of a lessening of environmental constraints (lithology) on the stochastic processes that generate stream networks. In the lower Cross river system, Udosen (2008) established a strong degree of interdependence $(60 \%$ of the correlation coefficient significant at 0.05 level) amongst the morphometric properties in Ikpa River Basin.

In the present study, the size of the basins correlates strongly with mean length of overland flow $(0.77)$; drainage intensity $(-0.81)$;drainage density (0.77); stream frequency $(-0.68$ and bifurcation ratio (0.65), all significant at 0.01 level. There also exist strong and negative relationships between the mean length of overland flow and drainage intensity (-0.94); stream frequency $(-0.68)$; and drainage density $(-1.00)$. These relationships are significant at $99 \%$ level. The stream frequency on the other hand, is linearly related to drainage intensity $(0.76)$; circularity ratio[0.66]and drainage density (0.67), while its relationship with mean length of overland flow is inverse $(-0.68)$. The only parameter that relates moderately with basin relief (local relief is elongation ratio $(0.42)$, this relationship is significant at 0.05 level and it is indicative of the fact that streams tend to flow through narrow depressions in areas with high relief and hence they are elongated in shape.

As expected, the mean length of order 1 streams is moderately related to the stream gradient (0.47), but inversely related to lemniscate K-factor. The relationship between elongation ratio and bifurcation ratio (0.54) corroborates earlier studies by Ebisemiju, 1986 and presupposes that the process of stream abstraction in the rugged topography of Obudu Plateau is bifurcation while extension of the length of stream segments, particularly order 1 is common in the relatively gentle terrain of Ikom and Abakaliki.

It is obvious from the summary of the morphometric characteristics of mature order -3 basins in the study area is that the river channels underlain by Precambrian Basement complex rocks[tributaries of Amire River] have restricted basin area[mean $=27.94 \mathrm{~km}^{2}$; very high values of basin relief (mean $=444.4 \mathrm{~m}$ ); high bifurcation ratio, mean of 3.94 and 
ranges from $2.67-7.1$; high stream frequency and drainage density $(0.33-1.19$, with a mean value of 0.69$)$ and $0.46-1.42 \mathrm{~km} / \mathrm{km}^{2}$, mean $=0.96 \mathrm{~km} / \mathrm{km}^{2}$ ) respectively. In addition the streams/ rivers flow through steep channel, the general channel slope ranges from $1^{\circ}$ to $6^{\circ}$ with a mean of $3.3^{\circ}$. On the other hand ,the morphometric characteristics of water bodies underlain by the Asu River Group in Ebonyi state and Ikom area have lower values of drainage density (0.29 and $\left.0.8 \mathrm{~km} / \mathrm{km}^{2}\right)$; large drainage basins $\left(30.59 \mathrm{~km}^{2}\right.$ and $51.77 \mathrm{~km}^{2}$; lower values of basin relief of $15.24 \mathrm{~m}$ and $30.48 \mathrm{~m}$ and consequently they flow through gentle slopes $\left(1^{\circ}\right.$ and $\left.4^{\circ}\right)$. This corroborates the assertion by Jeje (1991) and Udosen, (2008) that the process of stream abstraction in a rugged topography with very high relief is through bifurcation. Conversely, in the low terrain, river channels develop through elongation.

Table 5 Rotated Principal Components Loading* Matrix of the Morphometric Attributes of Third Order

\begin{tabular}{|l|l|l|l|l|}
\hline PARAMETERS & Factor 1 & Factor 11 & Factor 111 & Factor 1V \\
\hline Basin area & $-75^{*}$ & 1.9 & 60.4 & 23.1 \\
\hline Basin relief & 24 & 34 & -37.5 & 34.3 \\
\hline $\begin{array}{l}\text { Mean length } \\
\text { order 1 }\end{array}$ & -28 & $47.8^{*}$ & -4.25 & $66^{*}$ \\
\hline Channel gradient & -11 & 16 & 15.2 & $90^{* *}$ \\
\hline Bifurcation ratio & 6.7 & 5.6 & $94.6^{* *}$ & 4.9 \\
\hline Stream frequency & $83^{* *}$ & 17.9 & 2.5 & -14 \\
\hline Drainage density & $94^{* *}$ & 6.9 & -10.8 & 3.0 \\
\hline $\begin{array}{l}\text { Drainage } \\
\text { intensity }\end{array}$ & $98^{* *}$ & -6.4 & -7.2 & -11.7 \\
\hline $\begin{array}{l}\text { Mean length of } \\
\text { overland flow }\end{array}$ & $94^{* *}$ & -6.3 & 10.6 & -3.1 \\
\hline Form factor & 25 & $82^{* *}$ & 10.4 & -25.9 \\
\hline Elongation ratio & $53^{*}$ & $77^{* *}$ & -48 & -23.1 \\
\hline $\begin{array}{l}\text { Lemniscate K- } \\
\text { factor }\end{array}$ & 24 & $-94^{* *}$ & 12.7 & 7.8 \\
\hline Summary & 1 & 11 & 111 & $1 \mathrm{~V}$ \\
\hline Eigenvalue & 4.75 & 2.62 & 1.92 & 1.61 \\
\hline $\begin{array}{l}\text { Percentage of } \\
\text { total explanation }\end{array}$ & 36.55 & 20.13 & 14.80 & 12.42 \\
\hline $\begin{array}{l}\text { Cumulative \% of } \\
\text { total explanation }\end{array}$ & 36.55 & 56.69 & 71.49 & 83.90 \\
\hline
\end{tabular}

Principal component analysis was applied to 13 morphometric variables measured for the 22 third-order streams in Cross River basin. The four factor model account for $83.90 \%$ of the variation in the original data. The separate contribution of rotated factor is listed in table 3, for example factor 1 explains $36.55 \%$ of the variation in the data. It is quite obvious that factor 1 is predominantly related to drainage texture, or index of drainage dissection and is inversely related to basin size. It also relates strongly with the mean length of overland -flow. This relationship is expected since the mean length of overland flow is a reciprocal of drainage density. Factor 11 on the other hand, is essentially related to the variables that characterize basin shape viz;-form factor, elongation factor and lemniscate Kfactor[inversely related]. It is perhaps worth noting that the circularity ratio is the only index of basin shape that is not significantly related to other variables in the study area. Together factors 1 and11 account for almost $60 \%$ of the variance in the data set. The other factors contribute progressively less, and they are related to bifurcation ratio and stream gradient/mean length of order -1 respectively.

\section{CONCLUSION}

The study has revealed that the streams in the ancient basement complex rocks of Obudu/Obanliku have restricted area, high values of basin relief and high bifurcation ratio due to inability of streams to erode easily, unlike the weak sedimentary rocks. It is obvious that the morphometric properties of streams differ significantly between the ancient rocks and the sedimentary formations. This study has also shown that differences in geology constitutes a constraint on the degree of interdependence amongst the morphometric attributes of drainage basins and that the mature streams in the rugged topography of the upper Cross River system are characterized by elongated shape. The findings in this study corroborate the assertion by Abrahams[1972]. However, further research is necessary to determine the ideal shape of a river basin using the lower segment of the same Cross River system, particularly the tributaries draining Akwa Ibom State. 


\section{REFERENCES}

Abrahams, A. D., 1972. Factor analysis of drainage basin properties; evidence for streams abstraction accompanying the degradation of relief. Water Resources Research, 8, 624 - 33

Doornkamp, J. C. and King, C. A. M.,1971. Numerical Analysis in Geomorphology; an introduction. Edward Arnold pp1-96

Ebisemiju, F.S., 1976. The structure of the interrelationship of drainage basin characteristics' Unpublished Ph.D Thesis, University of Ibadan, Ibadan

Ebisemiju, F. S., 1985. Landscape degradation and the interdependence of drainage basin morphometric properties' Nigerian geographical journal.vol.28 and 29 nos. 1-2 pp 137-152

Ebisemiju, F. S., 1987. The Effects of Environmental Heterogeneity on the Interdependence of Drainage Basin Morphometric Properties and its implication for Applied Studies'. Singapore Journal of Tropical Geography, vol.8;114-28

Gardiner, V., 1978. Redundancy and Spatial Organization of Drainage Basin Form indices. An empirical investigation of data from north- west Davon' Transaction Institute of British Geographers New Series 3,416 - 431

Gregory and Walling., 1973. Drainage Basin Form and Process; a geomorphologic approach. Edward Arnold

Jeje, L. K., 1991. Urbanization and accelerated erosion. The case of Effon Alaaye in Ondo State' Paper presented at the third Annual seminar of the NGWG at the Bendel State University, Ekpoma $12^{\text {th }}$ September, 1991

Morisawa, M., 1957. Accuracy of Determination of Stream Lengths from Topographical Maps.' Transaction American Geographical Union 38, 86-8

Morisawa, M., 1968. Streams, their dynamics and Morphology. McGraw-Hill Book Company. New York

Udosen, C. E., 2008. Gully Erosion in Ikpa River Basin : a threshold phenomenon Time Communication, Lagos. Pp.295

Ukpong, C. O., 2005. Hydraulic Geometry of Iba Oku Stream Channels and its Implications for River Basin Management M.Sc. dissertation, Department of Geography, University of Uyo. 